\title{
Approaching Modern Technological Challenges Through the Traditions of Ibn Sīnā (980-1036)
}

\author{
Faroque Ahmed Khan, MB, MACP \\ State University of New York \\ Stony Brook, New York \\ King Fahd Medical City \\ Riyadh, Saudi Arabia
}

\section{Introduction}

$\mathrm{T}$ his presentation commemorates the remarkable contributions and achievements of Abū `Alī al-Husayn Ibn `Abdullah ibn Sīnā, known as Avicenna in the West. Born in 980 near Bukhāra in Uzbekistan, ibn Sīnā was the foremost medical scholar, philosopher, and educator in the world at the beginning of the second millennium, a thousand years ago. I have structured this talk as a conversation with ibn Sīnā. Let us assume ibn Sīnā has returned from barzakh (the period between death and resurrection) and is with us in Beijing. How might he address the issues regarding the use, limitations, and advantages the rapid proliferation of modern technology has created? I will present some of my own observations related to my work as an intensivist-pulmonologist and more recently as a spokesperson for the Islamic Center of Long Island in New York. I will present three case studies:

1. Do intensive care monitoring devices such as the Swanz Ganz catheter (SGC) really make a difference?

2. The case of Terri Schiavo in the United States brought into sharp focus the challenge of

Presented at the 39th Annual and 8th International Convention and Scientific Assembly of the Islamic Medical Association of North America, held in Beijing, China, July 25-28, 2006.

Correspondence should be directed to

Faroque Ahmed Khan, MB, MACP

Professor of Medicine

State University of New York

Stony Brook, New York

email:faroquekhan@yahoo.com caring for the hopelessly ill. Is it permissible and acceptable that she died from dehydration and starvation?

3. Joanne was born without a uterus. Can Joanne's mother, Martha, carry a fertilized ovum of Joanne and her husband, Robert?

Before we do that, let us refresh our memory regarding ibn Sinnā and the times during which he lived.

\section{Environment}

In the 7th century CE, Islam swept from Arabia through Egypt, North Africa, and Spain. Within 100 years, most of the ancient Greco-Roman world had been transformed into a far-reaching Islamic society. Greco-Roman literature such as the works of Hippocrates, Aristotle, and Galen were translated into Syriac, Aramaic, Persian, and Arabic. Libraries flourished; literature, poetry, and music were given priority in this Islamic society extending from Baghdad in the east to Qurtuba (Cordoba) and Tulayțila (Toledo) in the west.

\section{Education}

Education was emphasized. In 980, the year ibn Sīnā was born, every 12-year-old child in Baghdad could read and write. Caliphs' courts had physicians, scientists and literary scholars, and intellectual discourse was intense and widespread. It was in this environment that Ibn Sinnā was born and flourished.

Let us look at some key accomplishments over his brief 57-year life. ibn Sīnā was a medical scholar, philosopher, and educator. At 8 years of age, he memorized the Holy Qur'an. He completed his medical studies by age 16 . Over a period of 15 years he 
wrote the scientific encyclopedia "Al-Qānūn" (The Canon). This book remained a standard text for 700 years. It was the Index Medicus of its time. The Canon was translated into Latin, Hebrew, and English. Ibn Sinnā was educated by and worked with Christians, Muslims, Jews, and Zoroastrians. Ibn Sīnā diagnosed his own mortal illness almost 1000 years ago. He retired to his home in 1036 and gave away all his possessions. He immersed himself in the Holy Qur'an, his poetry, and Islamic faith. During Ibn Sīnā's time, death lay in the domain of faith, not medicine.

\section{Five Great Physicians}

During the period from 800 to 1300 AD, Islamic civilization was at its zenith, and in the medical field the following five stand out as extraordinary physicians:

1. al-Rāzī (Razes): medicine, epidemiology, ophthalmology, chemistry. Bagdad, Iraq (841926).

2. al-Zahrāwī: pioneer surgeon. Qurțuba, Spain (930-1013).

3. ibn Sīnā (Avicenna): philosophy, astronomy, poetry. Hamazan, Turjani, Iraq (980-1037).

4. ibn Rushd (Averroes): philosophy, medicine, law Ghirnāța, Spain (1126-1198).

5. ibn al-Nafîs: pulmonary circulation, blood. Damascus, Syria, and Cairo, Egypt (12081288).

\section{The Rise and Decline of Muslim Hospitals}

Hospitals flourished through generous endowments, and patients had easy access to health care. Furthermore, physicians were licensed. A good example of such a facility is the Mansur hospital in Cairo during the 13th century CE. Medical practice here included case reports; bedside teaching; examinations for licensure; specialty wards for fever, diarrhea, eyes, and wounds; and elegant rooms with piped music. Patients at discharge were given five gold pieces to provide them financial support during convalescence.

Some of the reasons for the success Muslims experienced were their encouragement of learning from all sources and their prohibition of wanton destruction. For example, the conquest of Makka during the time of the Messenger Muhammad all walle took place with minimal loss of life and property. Muslims encouraged cleanliness and personal hygiene, and they tolerated other religions. Muslim physicians maintained high standards because of their identification with an ascendant civilization, the high prestige society accorded the healing profession, rulers' involvement in public service, and adequate financing to run hospitals.

A reason for hospitals' relative decline was the centralized and despotic nature of political institutions. A conservative orthodoxy discouraged initiative and dissent. For example, printing presses were forbidden, imports were encouraged, and exports were discouraged. The Turks refused to adopt newer methods to control plague. The Janissaries destroyed the state observatory in 1580, alleging that it caused plague. ${ }^{a}$

Having learned a bit about this great civilization, I recommend the book Muslim Contributions to World Civilizations, ${ }^{1,2}$ which succinctly summarizes the accomplishments of the Muslims.

\section{Questions}

Let us now present our three cases and speculate how ibn Sīnā might have responded:

1. Do intensive care monitoring devices such as the $\mathrm{SGC}^{3}$ really make a difference?

2. The case of Terri Schiavo in the United States brought attention to the challenge of caring for the hopelessly ill.4 She died from dehydration and starvation. Is that permissible?

3. We have the tools that allow the creation of embryos outside the body. What are the guidelines for the appropriate use of these technologies?

aEditor's comment: The story of the decline of the practice of medicine in Muslim countries related here does not reflect the most recent research on this topic. See al-Hassan, AY, "Factors behind the decline of Islamic science after the sixteenth century" (http://history-science-technology.comArticles/ articles\%208.htm). The issue of the printing press is discussed in Mulder E, "Keyboard Calligraphy," Saudi Aramco World, 2007;58(4), p. 34-9 (http://www. saudiaramcoworld.com/issue/200704/keyboard.calligraphy.htm). For a discussion of the destruction of the Istanbul observatory, see Lunde P, Bilkadi Z, "Arabs and Astronomy", Saudi Aramco World, 1986;37(1):4-7 (http://www.saudiaramcoworld.com/ issue/198601/arabs.and.astronomy.htm). 
Case 1: Application of Monitoring Devices in Critically Ill Patients: Central Venous Pressure (CVP) or SGC?

A consultant is called in regarding a patient in his 40s who has adult respiratory distress syndrome (ARDS), most likely resulting from the recent outbreak of the avian flu. The patient is on mechanical ventilation with positive end-expiratory pressure (PEEP), high inspired oxygen, reduced lung compliance, and a dropping urine output. The patient is awake and follows commands. The question of appropriate monitoring of the patient's hemodynamics and fluid therapy is discussed by the consulting attending with the unit's house staff and the patient's internist. Two very different options result from the discussion. The first follows urine output and mental status closely and places a central venous line for monitoring of fluid balance. The other suggestion is to place a SGC because that will provide better assessment of hemodynamic status and result in better management.

\section{Case 2: End of Life Care: Terri Schiavo Case-Nutrition and Feeding in Persistent Vegetative State (PVS)}

Terri Schiavo, 41, died March 31, 2005, at the Pinellas Park hospice, where she had lain for years while her husband and her parents fought in the nation's most divisive-and most heavily litigatedright-to-die dispute. Although tragic, the plight of Terri Schiavo provides a valuable case study. The conflicts surrounding her situation offer important lessons in medicine, law, and ethics. The following is a summary of Ms. Schiavo's case.

On February 25, 1990, 26-year-old Terri Schiavo suffered a sudden cardiac arrest, the cause of which was not determined. She thereafter lapsed into a persistent vegetative state (PVS). She remained in a vegetative state for 15 years. Her husband, Michael Schiavo, had long sought to have the feeding tube taken out, arguing that she would not have wanted to be maintained in a vegetative state, but her parents fought to keep her alive. Members of the U.S. Congress, the Florida Legislature, and Florida Governor Jeb Bush intervened to keep Ms. Schiavo's feeding tube in place. On October 21, 2003, Governor Bush successfully pushed for an emergency act of the Florida Legislature to restore the feeding tube. The law became known as "Terri's Law." A lawsuit challenging its constitutionality was immediately filed. After several additional rulings and appeals in the courts and the involvement of the U.S. Congress, on
March 18, 2005, the feeding tube was removed, and 13 days later, Ms. Schiavo died. What are the Islamic guidelines regarding care of patients such as Ms. Schiavo? Is it permissible to withhold food and water in such cases?

\section{Case 3: Application of Technology: What Are the Limits and Who Sets Them?}

In Long Island, New York, Martha and Jack explained to their 14-year-old daughter, Joanne, that she had been born without a uterus, making it impossible for her to become pregnant or bear her own children. Comforting her daughter, Martha promised, "If someday you and your husband want to have a family, I will carry your babies for you." Nine years later, Joanne married Robert and began thinking about the possibility of having children. When Joanne reminded her mother Martha of the offer she had made, Martha said "Of course I meant it." Though she was 48 years old at the time, Martha was impregnated with embryos created from Joanne's eggs and her husband Robert's sperm and she delivered two babies. As a Muslim physician, I was asked to comment on the question on the permissibility of Martha's carrying the fertilized ovum of her daughter and son-in-law, Robert.

Having presented our three modern-day medical dilemmas, how might Ibn Sīnā respond? I can assume since Ibn Sīnā was so well grounded in knowledge regarding the Holy Qur'an, he might start off by sharing some relevant Qur'anic verses with us.

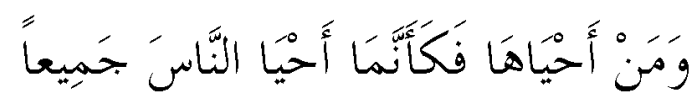

And if any one saved one life, it would be as if he saved the life of the whole people. ${ }^{5}$

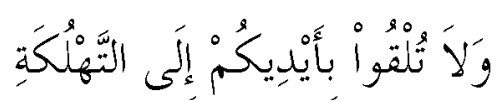

And do not with your own hands cast yourselves into destruction. ${ }^{6}$

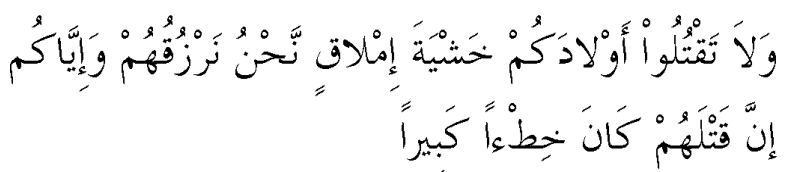

And slay not your children for fear of want. We shall provide for them and you. Lo! Their slaying is a great $\sin ^{7}$ 


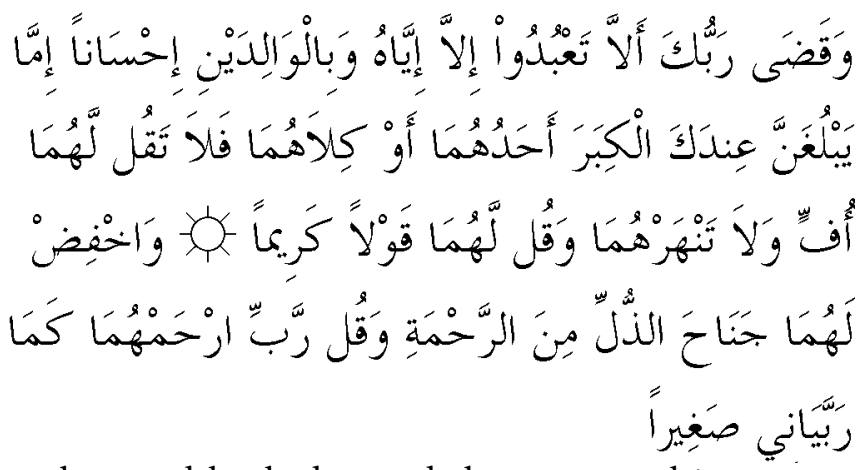

Thy Lord hath decreed that ye worship none but Him, and that ye be kind to parents. Whether one or both of them attain old age in thy life, say not to them a word of contempt, nor repel them, but address them in terms of honor. And, out of kindness, lower to them the wing of humility, and say: "My Lord! Bestow on them thy mercy even as they cherished me in childhood."8

Ibn Sinnā, besides having memorized the Qur'an, was well-versed in the works of others who preceded him and his contemporaries. So it is safe to assume that during his visit with us he would have read newspapers such as The New York Times, read a few books-perhaps mine, as well, Story of a Mosque in America ${ }^{9}-$ and read up on the accomplishments of others in the past millennium.

He would, I am confident, be very impressed with the advances in technology, particularly in the field of informatics and the rapidly expanding application of the Internet. He would be appalled by the wide gap between the "haves" and "have-nots." Two-thirds of the world's population lives in poverty, with 1.2 billion living on less than $\$ 1$ per day and 2.8 billion living on less than $\$ 2$ per day.

Ibn Sīnā might start off by commenting:

Questions are always the same, because science is a synonym of wisdom and philosophy that yields knowledge that is certain by virtue of its insight into causes.

\section{His Overall Impression of the Community}

Ibn Sina a would be impressed with the numbers and distribution of Muslims, with Indonesia being the largest Muslim country and ruled until recently by a Muslim female. He would quickly find out that Bangladesh, Turkey, and Pakistan also have or had female presidents and prime ministers. An estimated Muslim population of more than 1.2 billion is certainly very laudable, and its spread over the entire globe is indeed remarkable. He would certainly comment and perhaps lament on the quality of Muslims.

He might say:

While your numbers are at an all-time high, the quality is another matter. You have just five Nobel Laureates: Abdus Salaam, Ahmed Zewail, Shirin Ebadi, Naguib Mahfouz, and Muhammad Younus. While Muslims represent almost a quarter of the world's population, you, the Muslims, have less than $1 \%$ of the world's scientists.

In our time (that of Al-Rāzī, al-Zahrāwī, Ibn Rushd, Ibn Nafis) the status of Muslim scientists was very different. Others used to look to us for guidance. Frankly, I was pleasantly surprised that my book, al-Qānūn, ${ }^{10}$ remained a standard text equivalent to Index Medicus for more than 600 years and was translated into other languages.

Scholarship among Muslims and others must be a priority, and I do not mean rote memorizing of facts, figures, and texts. I mean real intellectual discourses.

To provide some constructive critique, I have broken the following into "A," "B," and "C." You like sound bites. In our time we used to sit face-to-face and discuss. Your lifestyles are very different. Here is my critique:

\section{“A"}

Accent: While speaking and expressing without accent is commendable, do not make correct accent an exclusive criterion for knowledge or piety.

Ancestry: Bilal's example. A black Abyssinian slave became the muezzin and first treasurer of an Islamic state. Islam is colorblind; the focus is on content and quality and not pedigree.

Agitation: There are a lot of demonstrations and emotional outbursts. I do not see a well-laid-out strategic plan. I am glad that IMANA has organized this high-caliber meeting. It is much needed.

Appearance: Wearing a phiran, shalwar kameez, thawb, beard, or turban' is fine, but that shouldn't be a priority. As to hijab, I will leave that for another day.

"B"

Believing: Quite a few Muslims are in hiding and are afraid to live the faith in public. "Closet Muslims" must believe in themselves, or they will suffer the fate of Muslims

bEditor's note: The phiran is a thick, loose shirt worn in Kashmir. The shalwar kameez is a pant, knee-length shirt combination from the Indian subcontinent. A thawb is an ankle-length garment with long-sleeves and stiff collars worn by men in the Arabian Peninsula. 
who migrated earlier and were totally assimilated and lost.

Belonging: Many of you who settled in the United States or the United Kingdom are still wondering, "Where is home?" I like Hassan Hathout's definition of home: "Where grandchildren live, not where grandparents are buried."11 Hassan Hathout is a good man. He left some important works for all of you. Faroque, I liked the chapter in your book where you incorporated the current healthcare crisis and some solutions in describing a khutba at the Islamic Center of Long Island. You must get engaged in addressing local issues. Think global but act local.

Behaving: Now I was appalled to see the scene on Fridays in several mosques when I visited Europe and the United States. You have these four-wheeled, fast-moving, gas-guzzling, environment-polluting cars. We used to live close to the mosques and went for prayers on foot or by horse. We made sure the animals were properly secured. I heard several neighborhoods objected to the parking around mosques on Fridays. You can do better and show civic sense; your jihad is winning the hearts and minds of your neighbors.

Boring: I attended a few Friday khutbas. There was too much vitriolic language, anger, blaming others, and past glory. There was very little focus on current issues and problem-solving. Your children are tuning out.

I have been rough on you, so far. You should deemphasize the four As (Accent, Ancestry, Agitation, and Appearance) and improve in the four Bs (Believing, Belonging, Behaving, and Boring). Now, let me leave you with four "Cs" to work on.

"C"

Competence: Excel in whatever you do in school, college, or your profession. I was pleased to learn that several of your alumni are making major contributions in health delivery, education, and research. You need to celebrate such accomplishments. You might be surprised to learn that the largest medical research organization in the world, the United States' National Institutes of Health (NIH), is headed by Elias Zerhouni, an Algerian Arab Muslim, and he earned his appointment through his competence and contributions to science. I am glad to see the recent profiles of Drs. Zerhouni, Qazi Mobinuddin, Hina Chaudhry, and Khalid Butt in your journal (JIMA).

Courage: You must speak out for justice, not just for Muslims but for all. The honor killings, suicide bombings, sectarian violence, and lack of religious facilities for nonMuslims in some Islamic countries are wrong. You must take the lead in speaking out about these injustices. You might like to consider supporting due process for
Guantanamo prisoners.

Character: Syed Ali, a gas station attendant in Brooklyn, saved a synagogue from burning.12 The rabbi said, "Ali is my hero." You must show the good side of Muslims. You do this by action.

Clarity: You informed me what the Robert S. Mueller, the director of the Federal Bureau of Investigations (FBI), told you about the vitriolic and hateful literature being circulated in some Islamic schools and mosques. In fact, Faroque, you showed me in a translation of the Qur'an by Mohsin Khan. In Ayah 7 of Sura al-Fātiha, the translators have added to the words "gone astray" the parenthetical text "like Jews and Christians". Such literature needs to be removed from circulation.

When I wrote Al-Qānūn, I synthesized the works of the Greek-Roman period and crystallized that heritage and incorporated many of its parts. There is nothing wrong in learning from others and adopting what is useful.

Now, let me conclude with a few other remarks. During my time, a thousand years ago, we had a close working relationship with Jews and Christians. In fact, Maimonides is a product of our time. Even Abba Eban, the Israeli representative to the United Nations, Knesset member, and minister in several governments, stated that the golden period for Jews was during the Muslim rule in Spain. He noted in his autobiography two periods when the Jewish culture truly flourished. The first and greatest was during the 400 years of Islamic Renaissance in the Iberian Peninsula, and the second one after the Jewish migration to the United States. ${ }^{13}$

Out of curiosity, I looked up the current status of the Jewish community and came across Steven Silbiger's book The Jewish Phenomenon. ${ }^{14}$ This small group of 13 million out of five billion (less than 1\%) has accomplished a lot, and it did not happen by accident. A lot of work went into it. In fact, the seven secrets I am going to share with your group are from this book. There is much to learn from the rather impressive accomplishments described in this book.

The seven secrets described by Silbiger in his book are fairly simple, and you can learn from this experience:

1. Understand that real wealth is portable; it is knowedge.

2. Take care of your own and they will take care of you.

3. Successful people are professionals and entrepreneurs.

4. Develop your verbal confidence.

5. Be selectively extravagant but prudently frugal.

6. Celebrate individuality: encourage creativity.

7. Have something to prove: a drive to succeed. 
On a recent visit to Israel I was impressed with the advances that this small country has made incorporating modern technology for the betterment of its Jewish citizens. I was told that Israel has the highest number of Nobel Laureates and scientists per capita population. On the other hand, I was appalled by how the state of Israel treats Palestinians.

Let me also advise you to make sure you combine your work with other activities so as to lead a balanced life. I used to enjoy poetry and philosophical discourses with colleagues. I found it quite relaxing. Let me now conclude with my answers to the three questions you asked:

\section{CVP or SGC for Monitoring Critically Ill Patients}

This example is a good one to focus on. Not too long ago it was common teaching that if one put a catheter close to or inside the heart there would be serious problems. It took the courage of Wermer Forssman, a young trainee in Eberswalde, Germany, to negate this idea. In 1929, against the advice of his supervisor, Dr. Schneider, he self-experimented and passed a catheter into his heart and confirmed this with an X-ray. In the 1940s, the pioneering work of André Cournand and Dickinson Richards in Bellevue Hospital of Columbia University in New York led to the development of cardiac catheterization for which Forssman, Richards, and Cournand received the Nobel Prize in Medicine/Physiology in $1956 .{ }^{15}$

In 1970 Harold James C. Swan and William Ganz discovered and refined the flotation catheter technique and thereby brought cardiac catheter techniques to the bedside. ${ }^{16}$ For the first time, physicians could measure the hemodynamics in seriously ill patients without moving them from the intensive care units. SGC use took off and in the early 1990s more than a million such catheters were used annually in the United States at a cost of more than $\$ 2$ billion. However, some, particularly Robin in $1985^{17}$ and Connors in 1996,18 raised some concerns regarding the abuse and overuse of the SGC. The National Heart, Lung, and Blood Institute (NHLBI), to its credit, put together groups of experts and determined that, when compared to the much simpler CVP line, the SGC did not offer any advantages and instead added to the cost of care and increased complications. ${ }^{19}$

Based on this review of literature, I, ibn Sin $\bar{a}$, would have to recommend using your clinical parameters, monitoring the patient's mental status, urine output, and lung compliance carefully, and use of the CVP if needed.

It is important to test all new advances in a prospective manner to see the effectiveness in improving outcomes and the cost-benefit ratio. Based on that information, make rational decisions. Thanks to Google and PubMed, I was able to retrieve several recent studies on this topic, and they all seem to conclude that CVP monitoring is just as effective as SGC monitoring with the added benefit of lower cost and fewer complications.

\section{Terri Schiavo Case}

This young patient had persistent vegetative state and legally, religiously, and morally was alive, though she was hopelessly ill. In our time such patients would be taken care of at home and receive tender care and die peacefully surrounded by members of family. I would not advocate stopping fluids and food. In my thinking that is not right and/or permissible. Also, I am concerned with the cost of caring for Ms. Schiavo in an institutional setting. I wondered why her parents and husband did not arrange for her care at home. My guess is that Ms. Schiavo's care cost the taxpayers more than $\$ 1$ million.

\section{Martha and her Daughter Joanne's Dilemma}

Joanne was born without a uterus and, after marriage to Robert, wanted to complete her family. Her mother, Martha, offered to carry the embryo made from Joanne's egg and her husband Robert's sperm.

In our time we did not have to face such queries because we did not have the technology available. There are many Qur'anic verses that clearly define motherhood,20-21 the importance of lineage ${ }^{22}$ and the role of marriage. ${ }^{23}$ Based on that, it would seem that carrying of the embryo by Martha is not permissible. ${ }^{24}$ However, we are also aware of the famous saying of the Prophet Muhammad allwalle that for every ailment there is a cure. I wonder if surrogacy may be the cure for the unique situation such as the case presented. However, you need to remember that in another narration of a similar hadith, the Prophet all' als added "but do not use prohibited means." 25 This issue needs further discussion and debate. Allah alu knows best.

I have a few general observations before I return to Barzakh.

\section{IMANA's Link and Collaboration with Other Medical Organizations}

The relief work done in Indonesia and Pakistan is commendable and your work and involvement in Federation of Islamic Medical Associations (FIMA) is a good example for the global Muslim umma (community). Also I suggest you develop formal links with other medical organizations. A good example would be the mini-fellowship program of the American College of Physicians. There is no reason why FIMA/IMANA cannot be a partner in this program. Collectively, you can advocate for better health access in the 
United States. It is appalling that in spite of having the highest health care expense, $14 \%$ of gross domestic product with more than $\$ 5000$ per capita cost, there are more than 40 million uninsured Americans. Something is wrong, and IMANA can take the lead in helping address this problem

\section{Quality of Care and Setting Standards-Center of Excellence}

I noticed many of you have immigrated from other countries. You are well aware of the highly variable standards and quality of care provided. With some wellthought-out programs, you can make a difference. There is an urgent need to develop centers of excellence in various professional fields in key Muslim countries e.g., Indonesia, Bangladesh, Pakistan, Egypt, Saudi Arabia, Iran etc. These centers should be magnets for students so they can excel in their respective fields.

\section{Tolerance for Other Faiths}

Some of you will be surprised to learn that 50 years before my birth, in January 929, Abd al-Rahmān III declared himself the caliph in Spain, commander of the faithful, caliph of the Islamic world, successor to the Prophet at the head of the entire Muslim community. A remarkable historical fact is that Abd al-Rahmān's prime minister was a Jewish rabbi, Hasdai. My guess is that most of you did not know this fact. You have a very long and rich tradition and history of tolerance of other faiths. Be proud of it; share it with others.

I really enjoyed reading Maria Rosa Menocal's book "Ornament of the World", in which she describes the great Andulasian civilization where Christians, Jews, and Muslims lived together in peace and excelled in doing good.26 I particularly liked the chapter "Grand Vizier in a Grand City." This chapter is devoted to the rabbi who was the Prime Minister of Abd Rehman. ${ }^{27}$ Another book worth reading, particularly for those living in the West, is "What's Right with Islam" by Imam Feisal Abdul Rauf.28 This book lays out a very clear work plan for Muslims in the West. Let me, ibn Sin $\bar{a}$, conclude with the eternal message from the Holy Qur'an:

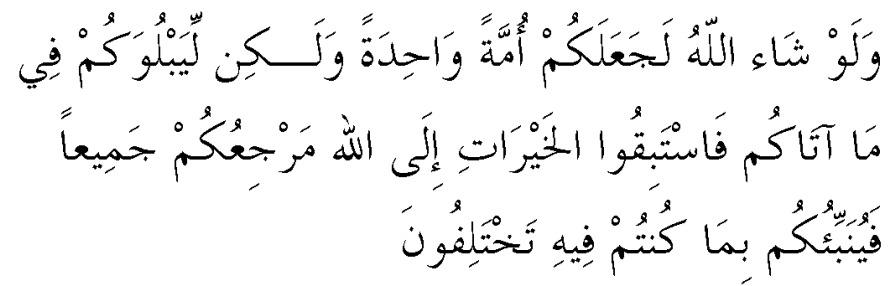

If Allah had so willed, He would have made you a single People, But (His plan is) to test you in what He hath given you; So strive as in a race in all virtues [author emphasis]. The goal of you all is to Allah; it is He that will show you the truth of the matters in which you dispute. ${ }^{29}$

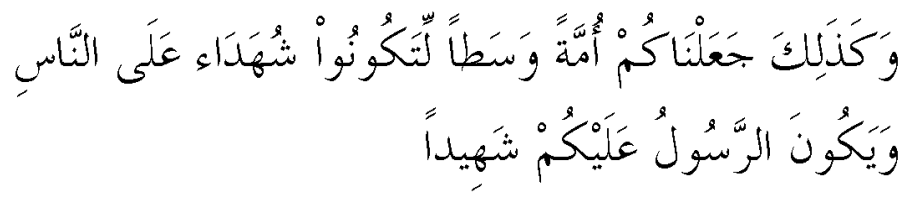

And thus We have created you a moderate nation that you may be a witness unto mankind even as the Messenger is a witness unto you. ${ }^{30}$

Clearly Muslims, in particular American Muslims, have a challenge ahead of them. Hopefully my brief observations will be helpful in providing some guidance. May Allah als. bless all of you.

\section{References}

1. Muslim Contributions To World Civilization. Ahmed MB, Ahsani S, Siddiqui D (eds).-The International Institute of Islamic Thought: Herndon,VA; 2005.

2. Khan, FA. Muslim Contributions to World Civilization (review). J Islam Med Assoc. 2006;38:64-5. 3. Hakim FA, Khan FA. Tale of Swan Ganz (pulmonary artery) catheter. J Islam Med Assoc. (in press).

4. Khan, FA. The right to die: some personal reflections on the Terri Schiavo case and the role of hydration and nutrion in hopelessly ill patients. J Islam Med Assoc. 2006;38:6-9.

5. Glorious Qur'an, Chapter 5, Verse 32.

6. Glorious Qur'an, Chapter 2, Verse 195.

7. Glorious Qur'an, Chapter 17, Verse 3.

8. Glorious Qur'an, Chapter 17, Verses 23-24.

9. Khan, FA. Story of a mosque in America. Cedar Graphics: Cedar Rapids, Iowa;2001.

10. Contents of Ibn Sina's Canon of Medicine in English [web page]. Saab Medical Library, American University of Beirut. Available from http://ddc.aub.edu.lb/projects/saab/avicenna/contents-eng.html [Modified 2007 Mar 26; Accessed 2007 Dec 13].

11. Hathout $\mathrm{H}$. Reading the Muslim mind. American Trust Publications: Plainfield, IN;1995. 
12. Ramirez, J. Gas station attendant honored for helping save Brooklyn synagogue [web page]. NY1.com. Available from: http://www.ny1.com/ny1/content/index.jsp?stid=9 \&aid=27105 [Modified 2003 Jan 10; Accessed 2007 Dec 13].

13. Eban A. Abba Eban: an autobiography. Random House: New York;1977.

14. Silbiger S. The Jewish phenomenon: seven keys to the enduring wealth of a people. Longstreet Press: Atlanta, GA;2000.

15. Altman LK. Who goes first: the story of self experimentation in medicine. University of California Press: Berkeley; 1998.

16. Swan HJ, Ganz W, Forrester J, et al. Catheterization of the heart in man with use of a flow-directed balloon-tipped catheter. New Eng J Med. 1970;283:44751.

17. Robin ED. The cult of the Swan-Ganz catheter. Overuse and abuse of pulmonary flow catheters. Ann Intern Med 1985;103:445-9.

18. Connors AF Jr, Speroff T, Dawson NV, et al. The effective of right heart catheterization in the initial care of critically ill patients. SUPPORT Investigators. JAMA 1996;276:889-97.

19. National Heart, Lung, and Blood Institute Acute Respiratory Distress Syndrome (ARDS) Clinical Trials
Network; Wheeler AP, Bernard GR, Thompson BT, Schoenfeld D, Wiedemann HP, deBoisblanc B, Connors AF Jr, Hite RD, Harabin AL. Pulmonary-artery versus central venous catheter to guide treatment of acute lung injury. N Engl J Med. 2006 May 25;354(21):2213-24.

20. The Glorious Qur'an, Surah 58, Verse 2.

21. The Glorious Qur'an, Surah 16, Verse 78.

22. The Glorious Qur'an, Surah 25, Verse 54.

23. The Glorious Qur'an, Surah 16, Verse 72.

24. Fadel HE. Islamic sharî̀ a rulings on new reproductive choices. J Islam Med Assoc. 2005;37:70-7.

25. Sunan Abī Dāwūd. Kitāb al-țibb (27). Bāb fī aladwiyya al-makrūha (11). Hadith 3870. Available from http://www.muhaddith.org.

26. Khan FA. The ornament of the world: how Muslims, Jews, and Christians created a culture of tolerance in medieval Spain by Maria Rosa Menocal (book review). J Islam Med Assoc. 2005;37:45-6.

27. Menocal MR. The ornament of the world: how Muslims, Jews, and Christians created a culture of tolerance in medieval Spain. Little Brown \& Company: New York;2002.

28. Rauf FA. What's right with Islam. Harper Collins: San Francisco;2004.

29. Glorious Qur'an, Chapter 5, Verse 48

30. Glorious Qur'an, Chapter 2, Verse 143. 